\title{
Internet Usage Habits as a Part of Distance Higher Education
}

\author{
Firat Tufan \\ Istanbul University, Turkey
}

\begin{abstract}
Within the scope of this study, which deals with distance education method as a communication process, a focus group interview was conducted with voluntary students who were randomly selected from various areas/majors at the Department of Distance Education in Istanbul University in order to determine the relationship between their general Internet usage habits and their Internet usage as a part of distance learning and in line with their expectations. The questions posed for the students during the interview process were drawn up on the basis of Internet medium serving a mass medium and for multi-purposes. The study revealed a positive relationship between general Internet usage habits of distance education students and their particular Internet usage habits during their education. It is concluded that the ability of students to adapt to social media applications and especially to social networks, which are the latest Internet applications based on interactive communications, is considerably high. The expectations of the students from the latest Internet applications are also high when it comes to distance education process.
\end{abstract}

Keywords: Distance Education; Internet usage habits; Information and communication technologies in education; Communication

\section{Introduction}

Learning, which is a prerequisite to improve living conditions on a continuous basis and survive, has been put into effect through various methods since the creation until now as one of humankind's most basic needs. People are able to learn, thanks to their mind, senses and life experiences. The variation of such factors varies by persons has lead to more efficiency in learning. Instructional technology includes all teaching platforms, teaching methods, theories, plans and trends. It is continually being redesigned with ever-developing technology. Each new technology becomes a part of our lives as long as it is effective for learning and teaching. The globalized world has made education international as many other things in our lives. However, the biggest step was taken upon the development of the computer and Internet technologies. Completed and developed infrastructural works have led to the transformation of the learning and teaching practices. Today's information and communication technologies (ICTs) call for the design of effective learning and teaching. Highly interactive distance education, which is independent of time and space, has been dubbed a learning and teaching method for today and future.

Even though distance education dates back to the early $20^{\text {th }}$ century, it has been carried out effectively online within its current form since the mid-1990s. Since 2000s, Internet has been widely used around the world. Due to the fact that a variety of contents and services offered 
by media, the purpose of Internet usage has also diversified at the same rate. In today's world, making use of Internet for learning and teaching purposes is of capital importance. We can find a virtual version of our lives online in an adapted form. Learning and teaching rank among the most important facts in human life. Therefore, the importance of this process will be further understood by adapting to Internet.

The main purpose of this study is to determine the role of Internet, which is a major variable for distance learning methods, in learning-teaching processes along with the usage diversity and multiple options it offers. This determination has revealed communicative expectations with regard to the current status and helped to offer recommendations. In addition, the adaptation of students to Internet and their usage practices have pointed to a requirement for contents produced in line with a media-oriented fashion.

Around the world, the studies about distance education methods generally are carried out from the pedagogical, technological and engineering perspectives. Pedagogical perspectives deal with the question of 'how one learns' in a traditional sense for distance education putting forward learning theories and it seeks an answer accordingly. Technological perspectives are comprised of used technological materials in an instrumental sense for distance education. Engineering perspectives involve media design and computer automation programs. Today, all the perspectives are expressed mostly in the context of an Internet-based distance education method.

In this study, the center of such perspectives is related to a communication process. This study is concerned about how communication is made more effective through tools and contents of Internet as the most widely-used distance learning platform and it specifically affects automation programs. The study aims at establishing a proper communication design for distance education methods to bring the expectations of students into light.

The fundamental assumption of this study is that a distance learning-teaching process is a communication process and that people benefit from Internet for many purposes. This leads to an effect on the role of a learning process. Due to the nature of the platform, distance learning offers a constructive perspective.

\section{Internet-Based Distance Education and Communication Process}

Internet is the fastest growing communication tool on all media platforms. The adoption rate of Internet has surpassed others. It took thirty years for radio to grow into a popular medium while it took thirteen years for television. Internet has reached out to 40 million users in a short period of 4 years (Holtz, 2002, p.4).

Mayfield (2008, p.7) defines social media as "a group of new types of online media, which share most or all of the following characteristics: participation, openness, conversation, community and connection. A good way to think about social media is that all of this is actually just about being human beings. Sharing ideas, cooperating and collaborating to create art, thinking and commerce, vigorous debates and discourses, reaching out to people who might turn out to be good friends, allies and lovers - it is basically what our species has built several civilizations on. 
None of the preceding technologies, except Internet, was able to provide an ability to communicate for users as today's blogs and social networking sites do (Rheingold, 2000, p.301). Recently, a new "wave" of Internet-based applications has emerged, often described as "Web 2.0" or "social media". Such Internet applications pave the way for a greater interaction between users and applications through user-generated contents. Such contents are varied, including photographs, videos, texts, and sophisticated media settings (Komito \& Bates, 2009, p.233).

Social networks are used for many different purposes at the present time and there are many sites on such sharing networks. They have a main purpose as online interaction and provide communication to appeal to the target audience and formal customized features. It is possible to encounter so many social networking services as social networks which target professional work life and establish special or unique interpersonal relations. Social networks have become widespread as the most-preferred communication means for individuals to communicate with each other.

What Internet offers for the communication process and how it does it is one of the most critical issues in terms of distance education practices. Learning is also a communication process and Internet has served as a tool at this point. Therefore, all of the above make the details of the implementation for Internet communication quite important. People now awake to their learning acquisition with the returns of communication processes on Internet by meeting the communication needs. In this regard, the design of distance education and mediating automation programs are required to be drawn up in line with the dual contribution of Internet for distance education.

It is commonly assumed that the educational perspective of the $21^{\text {st }}$ century is independent from time and place, oriented towards objectives and results, student-centered, weighted active team work, directed to receive training and it should involve differences in skills and language. In addition, it is considered that education of $21^{\text {st }}$ century has two important facts. These facts are lifelong learning and information society. In the information society, individuals gain knowledge to a great extent. To be able to provide this training, the necessity of Internet usage is explicitly emphasized when it comes to education (Aggarwal, 2000).

Web-based learning entails contents on a web browser (not just activities), and actual learning materials delivered in a web format. In this respect, web-based learning is analogous with textbooks, where the content determines whether a book is a novel, a report, or a textbook. Simply offering computer-based training (CBT) for download from a web site is not web-based learning since there is no learning content in a web format. The web, which allows to browse learning contents (even linearly) is a key feature of web-based learning. A web-based learning content is typically retrieved from a web site whereas alternative solutions are approved as well (a hypertext web does not require Internet or any network) (Tsai \& Machado, 2002).

Perception is defined as a process of knowledge collected systematically by one's brain (Tight, 2007, p.32). Perceptual learning modalities (also known as modes or styles) refer to the way information is extracted from a medium during a learning process to assist in perception, organization, and processing. There are many ways to define a learning style whereas one common system emphasizes the perceptual or sensory inputs of information: Aural (or auditory), visual, and kinesthetic (or tactile). While individuals may opt for one particular 
modality, some others may as well easily alternate among multiple modalities or offer no dominant style (Barbe, Swassing, \& Milone, 1979).

It is not only the stimulus that determines the qualification of perception at a certain moment, but also the personal history of the sensor, way of thinking, mental style, motivation and as well as other factors. All these refer to as an experience space of individuals (Inceoglu, 2010, p.108). It is a fact that the environment shapes our perceptions. All types of physical structures in terms of environment relay some messages on how we need to think. Our personal history in real life, way of thinking and motivation emerge as an important stimulus in a virtual environment.

The relation between a student and a learning environment is a determiner in learning styles. A learning style, either dependent or independent from any space is directly related to the learning environment. Past experiences, experimental factors and habits are influential in deciding on a learning style. Various personalities create various learning styles.

Internet-based teaching methods used for distance education provide an opportunity to offer customized options perceptually for each individual thanks to multimedia applications, synchronous and asynchronous content delivery and high-level interaction means. However, as previously stated, Internet is used for many purposes as it is multi-dimensional and tumultuous. Therefore, turning Internet into classroom brings about some challenges and disadvantages.

It is not possible to avoid perceptual differences in a communication process. However, Oskay $(1999$, p.42) reminds that the symbols used for coding a message must be familiar to the target audience who is supposed to send, receive, and comment on a message. At the same time, a message must be designed to attract the attention of the target audience so that it can have an impact on recipients.

Internet has grown into a social space rather than just a communication tool. This space creates new forms of social relations and covers the entire period of human life. People, who also exist in the outside world, making sense of it, regulate their own inner world. In case of inconsistency between an external and an inner world of a human being, such inconsistency and uneasiness are certain to be sensed by individuals in their real lives (Poster, 1997, p.206).

Studies have demonstrated that a personal uncertainty and ambiguity decreases in an enriched online environment and people feel themselves further belonging to an environment (Benson \& Harkavy, 2000, p.49).

The Internet-based distance education method is defined as the distribution and management of learning means by making use of a computer, networking, and web-based technologies in order to assist in individual behaviors and improvement (Hillage \& Pollard, 2001, p.20).

When proper methods and technologies for the structure of education in an Internet-based distance education system are put into use, it would be feasible to provide a high-level interaction among students and thus receive feedbacks from learners on a regular basis. It can also achieve an effective result for traditional education. In particular, the interaction between a learner and a teacher is of capital importance. Apparently, technological proficiencies is of 
vital importance in this process. Inadequacies and difficulties on technical devices can reduce motivation on learners and teachers.

Some studies related to habits and accomplishments or satisfaction shows that there is a significant relation between habits and an e-learning process. Satisfying experiences with regard to Internet-based learning technologies is therefore believed to have a direct effect on a student's intention to continue to use Internet. A research result shows that habits have a significant moderating effect on the relation between intention and continuous usage of Internet-based learning technologies. These results have several implications for theoretical and practical aspects (Limayem \& Cheung, 2011). The adoption of a new technology is just the first step toward an overall success. An information system implementation can truly be considered 'a success' once a significant number of users go beyond the initial adoption and make use of information systems on a continuous basis. Like many other studies on the usage of information systems suugest, this also relies uniquely on intention as the primary indicator for continuous usage of information systems. However, frequently-repeated behaviors tend to become a major part of daily lives, and it may become freed to some extent resulting from the necessity of making informed decisions. Thus, when behaviors become habitual, the impact of intention on behaviors decreases (Bhattacherjee, 2001).

Sharpe and Benfield (2005) reviewed the experiences and studied the habits of e-learners in higher education in order to identify areas worthy of future investigations. They reported some connections among habits and performances and suggested a deeper investigation into eliciting such experiences, habits, and strategies of effective e-learners. Thus, recent developments in distance learning technologies have grabbed the attention of researchers regarding how pedagogical perspectives are required to serve within this framework.

\section{Importance and Purpose}

All around the world, especially in higher education systems, many learning and teaching forms are offered for learners in line with an Internet-based distance education method. This ever-increasing trend creates a major industry while the social impacts of this trend also manifest themselves. In this respect, today's web-based distance education inputs and outputs are of major importance.

The present study, based on this matter, aims at identifying the current status of distance higher education. At this time, it seeks to reveal various aspects of the current status and to make some points on how we can make use of it more effectively. In addition, it aims at making it better and eliminating challenges.

\section{Hypothesis}

The fundamental assumption of this study is that a distance learning-teaching process is a communication process, and people benefit from Internet for many purposes. This situation paves the way for an effect on the role of a learning process. In this research, each distance education student is acknowledged an Internet user. The reason why this is the case is the fact that they perform their learning practices on Internet. At the same time, the distance 
education method is considered a constructive perspective since it offers a student-centered point of view.

Hypotheses to be tested within the scope of the current study are as follows:

1) General Internet Usage habits of students reflect their Internet Usage habits during educational studies.

2) Multi-dimensional and tumultuous Internet leads to distraction during learning activities that require intensive attention.

3) The distance education method, though it is fed by traditional teaching methods, creates a new communication way for learners and teachers.

4) The potential and what Internet offers lead to an increase in expectations of learners adapting to Internet.

\section{Method}

The purpose of the study is to determine general Internet usage habits and Internet usage habits as a part of educational studies of students studying at Istanbul University in line with the distance education method. Internet also serves as a major platform for students to learn in this system. Therefore, it is important to gain insight into how they use Internet and other services offered by Internet for educational purposes.

The study is conducted as a part of a focus-group interview with 12 students to further learn about the details of the relation between distance learning and communication processes. As a part of the interview, some questions were posed in an effort determine Internet usage habits and find out most-preferred media tools.

For the interviews, the participants were selected randomly to represent various departments and majors. Among them, 4 of the participants are from the Department of Radio TV and Film, 3 students from the Department of Public Finance, 2 from the Department of Labor Economics, 2 from the Justice Vocational School, and 1 from the Department of Banking and Insurance. All the students were randomly selected on a voluntary basis. The participants are comprised of 1 freshman, 3 sophomores, 4 juniors and 2 seniors. The age of participants ranged from 21 to 31. The interviews with participants were carried out on July 6, 2013 in the official premises for the Faculty of Communication, Istanbul University. The participants were divided into 2 groups while the interviews for each 6-person groups were conducted for 1 hour without any pause.

\section{Findings}

The questions posed within the scope of the Focus Group Interviews were presented to the participants in a semi-structured fashion. The interviews were performed by a moderator and a reporter through 'note-taking', 'an information form' and 'a micro voice recorder'. The data 
obtained during the interviews were processed by Kruger's (1994) 'Focus Group Information Form'.

The participants have informed of the codes ranging from K1 to K12. At the same time, they were divided into categories in accordance with their fields of study. PRTS refers to the department of Radio TV and Film, PM refers to the department of Public Finance, PCE refers to the department of Labor Economics, PAMYO refers to the Justice Vocational School and PBS refers to the department of Banking and Insurance.

The questions were posed as follows:

S1= For what purposes do you use Internet most?

S2= For what purposes do you use social networks most?

S3 = How would you like distance education courses offered in terms of content and materials? S4= What communication tools would you prefer most for your distance learning process?

$\mathrm{S} 5=$ What tools would you prefer most to communicate with your instructors?

$\mathrm{S} 6=$ What tools would you prefer most to communicate with your classmates?

$\mathrm{S} 7=$ What tools would you prefer most to communicate with the registrar's office?

S8= Do your general Internet usage habits have an effect over your Internet usage habits in terms of distance education?

In a focus group study, the issues are concentrated by most of the participants and given answers were processed and analyzed in consideration of the frequency of words and phrases'. The data set is shown below:

Table 1. The Focus Group Interview Data Set

\begin{tabular}{|c|c|c|c|c|c|}
\hline \multicolumn{4}{|c|}{ The date of the focus group: } & \multicolumn{2}{|l|}{ July 6, 2013} \\
\hline \multicolumn{4}{|c|}{ The place of the focus group: } & \multicolumn{2}{|c|}{$\begin{array}{l}\text { İstanbul University, Faculty of } \\
\text { Communication, D4 }\end{array}$} \\
\hline \multicolumn{3}{|c|}{ Number of participants / Description: } & & \multicolumn{2}{|c|}{$\begin{array}{l}12 \text { - Istanbul University Distance } \\
\text { Education Students }\end{array}$} \\
\hline $\begin{array}{l}\text { Codes of } \\
\text { Questions }\end{array}$ & $\begin{array}{c}\text { Codes of } \\
\text { Department }\end{array}$ & $\begin{array}{c}\text { Codes of } \\
\text { Participants }\end{array}$ & View (A & answers) & Focus Points \\
\hline S1 & PRTS & $\begin{array}{l}\mathrm{K} 1, \mathrm{~K} 2, \mathrm{~K} 6, \\
\mathrm{~K} 8\end{array}$ & $\begin{array}{r}\text { - Communicat } \\
\text { corresponde } \\
\text { entertainme } \\
\text { activities suc } \\
\text { music and w } \\
\text { under entert } \\
\text { - Communicat } \\
\text { a curriculum } \\
\text { consider acti } \\
\text { listening to r } \\
\text { watching a n } \\
\text { entertainme } \\
\text { - Communicat } \\
\text { following ne } \\
\text { networks (I } r \\
\text { Facebook.) }\end{array}$ & $\begin{array}{l}\text { n, business } \\
\text { e, } \\
\text { (I consider } \\
\text { as listening to } \\
\text { ching a movie } \\
\text { nment category) } \\
\text { n and following } \\
\text { ntertainment (I } \\
\text { ties such as } \\
\text { sic and } \\
\text { vie under } \\
\text { categories.) } \\
\text { g with friends, } \\
\text { through social } \\
\text { stly use }\end{array}$ & $\begin{array}{l}\text { - Communication } \\
\text { - Entertainment } \\
\text { - Information } \\
\text { - News }\end{array}$ \\
\hline
\end{tabular}




\begin{tabular}{|c|c|c|c|c|}
\hline & & & $\begin{array}{l}\text { - Communication and } \\
\text { information, entertainment. I } \\
\text { watch a movie and listen to } \\
\text { music. }\end{array}$ & \\
\hline & PM & K3, K4, K7 & $\begin{array}{l}\text { - Social networks, information, } \\
\text { work, entertainment. } \\
\text { - Information, Social networks, } \\
\text { Communication. } \\
\text { - To communicate for work (I } \\
\text { use for work mostly.) }\end{array}$ & \\
\hline & PÇE & K5, K9 & $\begin{array}{l}\text { - Entertainment, research, } \\
\text { information, following news. } \\
\text { - Communicating with friends, } \\
\text { entertainment, reading about } \\
\text { news. }\end{array}$ & \\
\hline & PAMYO & K10, K11 & $\begin{array}{l}\text { - Communicating with friends, } \\
\text { playing games, killing some } \\
\text { time, reading about news. } \\
\text { - Information, communication, } \\
\text { play around }\end{array}$ & \\
\hline & PBS & K12 & $\begin{array}{l}\text { - Communication, } \\
\text { entertainment, sharing } \\
\text { information and news. }\end{array}$ & \\
\hline \multirow{4}{*}{ S2 } & PRTS & $\begin{array}{c}\mathrm{K} 1, \mathrm{~K} 2, \mathrm{~K} 6, \\
\mathrm{~K} 8\end{array}$ & $\begin{array}{l}\text { - Communication. } \\
\text { - Communication. } \\
\text { - I use just for entertainment. I } \\
\text { follow my friends. } \\
\text { - Communication, making new } \\
\text { friends and educational } \\
\text { content videos. Especially } \\
\text { "how to" videos. }\end{array}$ & \multirow[t]{4}{*}{$\begin{array}{l}\text { - } \text { Communication } \\
\text { - } \text { friends } \\
\text { - Entertainment } \\
\text { - News } \\
\text { - Information }\end{array}$} \\
\hline & PM & $\mathrm{K} 3, \mathrm{~K} 4, \mathrm{~K} 7$ & $\begin{array}{l}\text { - Communication, news, } \\
\text { information and } \\
\text { entertainment. I incorporate } \\
\text { entertainment into } \\
\text { communication purposes. } \\
\text { - Communication, information, } \\
\text { entertainment (we definitely } \\
\text { exist for entertainment on this } \\
\text { platform.) } \\
\text { - I mostly use for reading about } \\
\text { news. (Tabloid press } \\
\text { 'paparazzi' also included.) }\end{array}$ & \\
\hline & PÇE & K5, K9 & $\begin{array}{l}\text { - News, communication, } \\
\text { entertainment } \\
\text { - Communication, to have fun, } \\
\text { sharing information and news. }\end{array}$ & \\
\hline & PAMYO & K10, K11 & $\begin{array}{l}\text { - Reading about news, sharing } \\
\text { information, to have fun, to } \\
\text { communicate with friends. } \\
\text { - Communication, news, } \\
\text { information, entertainment }\end{array}$ & \\
\hline
\end{tabular}




\begin{tabular}{|c|c|c|c|c|}
\hline & PBS & K12 & $\begin{array}{l}\text { - Communication, information, } \\
\text { to have fun }\end{array}$ & \\
\hline \multirow{5}{*}{ S3 } & PRTS & $\begin{array}{l}\mathrm{K} 1, \mathrm{~K} 2, \mathrm{~K} 6, \\
\mathrm{~K} 8\end{array}$ & $\begin{array}{l}\text { - I would prefer multiple } \\
\text { contents but it depends on } \\
\text { the scope of the course. } \\
\text { - It depends on the scope of } \\
\text { course. Contents are } \\
\text { generally sufficient. } \\
\text { - I would prefer audio-visual } \\
\text { contents. } \\
\text { - I would prefer audio-visual } \\
\text { contents. I do not like writing, } \\
\text { my visual memory is stronger. }\end{array}$ & \multirow[t]{5}{*}{$\begin{array}{l}\text { - Varies depending } \\
\text { on the course } \\
\text { - Audiovisual } \\
\text { - Multi-contents } \\
\text { - Written } \\
\text { - Figures and } \\
\text { diagrams for } \\
\text { assistance }\end{array}$} \\
\hline & PM & $\mathrm{K} 3, \mathrm{~K} 4, \mathrm{~K} 7$ & $\begin{array}{l}\text { - Written mostly. } \\
\text { - I would prefer written mostly, } \\
\text { but audiovisual for support } \\
\text { - I would prefer audiovisual } \\
\text { contents. }\end{array}$ & \\
\hline & PÇE & $\mathrm{K} 5, \mathrm{~K} 9$ & $\begin{array}{l}\text { Primarily written, audiovisual } \\
\text { for support and figures and } \\
\text { diagrams may be brief. } \\
\text { - Audiovisual. }\end{array}$ & \\
\hline & PAMYO & K10, K11 & $\begin{array}{l}\text { - Written and visual. } \\
\text { - I would prefer multi-contents } \\
\text { included all. }\end{array}$ & \\
\hline & PBS & $\mathrm{K} 12$ & - Written and visual. & \\
\hline \multirow{5}{*}{ S4 } & PRTS & $\begin{array}{l}\mathrm{K} 1, \mathrm{~K} 2, \mathrm{~K} 6, \\
\mathrm{~K} 8\end{array}$ & $\begin{array}{l}\text { - Social networks } \\
\text { - Face to face meetings, } \\
\text { message boards, e-mails. } \\
\text { - Telephone, Facebook } \\
\text { - Social networks }\end{array}$ & \multirow{5}{*}{$\begin{array}{l}\text { - Social networks } \\
\text { - } \text { Macebook mostly) } \\
\text { - E-mail } \\
\text { - Web site } \\
\text { - Telephone } \\
\text { - Face to face } \\
\text { meetings }\end{array}$} \\
\hline & PM & K3, K4, K7 & $\begin{array}{l}\text { - Social networks, notice boards } \\
\text { on networks } \\
\text { - Social networks } \\
\text { - Telephone, message boards, } \\
\text { e-mail }\end{array}$ & \\
\hline & PÇE & K5, K9 & $\begin{array}{l}\text { - Telephone or web sites } \\
\text { - E-mail, social networks }\end{array}$ & \\
\hline & PAMYO & K10, K11 & $\begin{array}{l}\text { - Telephone, social networks } \\
\text { - Web sites, e-mail, social } \\
\text { networks }\end{array}$ & \\
\hline & PBS & K12 & - Facebook, telephone & \\
\hline & PRTS & $\begin{array}{l}\mathrm{K} 1, \mathrm{~K} 2, \mathrm{~K} 6, \\
\mathrm{~K} 8\end{array}$ & $\begin{array}{l}\text { - E-mail (I am forced to use e- } \\
\text { mail since not all the } \\
\text { instructors have a facebook } \\
\text { account.) } \\
\text { - Face to face } \\
\text { - Telephone } \\
\text { - Message boards during a live } \\
\text { course, e-mail generally. }\end{array}$ & \multirow[t]{2}{*}{$\begin{array}{l}\text { - E-mail } \\
\text { - Face to face } \\
\text { - Telephone } \\
\text { - Message board } \\
\text { during live course }\end{array}$} \\
\hline & & & - E-mail & \\
\hline
\end{tabular}




\begin{tabular}{|c|c|c|c|c|}
\hline \multirow{4}{*}{ S5 } & PM & K3, K4, K7 & $\begin{array}{l}\text { - E-mail } \\
\text { - E-mail }\end{array}$ & \\
\hline & PÇE & K5, K9 & $\begin{array}{l}\text { - I do not need to communicate } \\
\text { with instructors but I call the } \\
\text { school if I need. They forward } \\
\text { me. } \\
\text { - I communicate via social } \\
\text { networks if they have, if they } \\
\text { have not, I communicate via e- } \\
\text { mail or telephone. }\end{array}$ & \\
\hline & PAMYO & K10, K11 & $\begin{array}{l}\text { - E-mail } \\
\text { - E-mail } \\
\end{array}$ & \\
\hline & PBS & K12 & - E-mail, message boards & \\
\hline \multirow{5}{*}{ S6 } & PRTS & $\begin{array}{l}\mathrm{K} 1, \mathrm{~K} 2, \mathrm{~K} 6, \\
\mathrm{~K} 8\end{array}$ & $\begin{array}{l}\text { - Facebook, face to face, } \\
\text { telephone } \\
\text { - Social networks, face to face, } \\
\text { telephone } \\
\text { - Telephone, Internet (Facebook } \\
\text { mostly) } \\
\text { - Social networks, telephone }\end{array}$ & \multirow[t]{5}{*}{$\begin{array}{l}\text { - Social networks } \\
\text { (Facebook mostly) } \\
\text { - Telephone } \\
\text { - Face to face }\end{array}$} \\
\hline & PM & $\mathrm{K} 3, \mathrm{~K} 4, \mathrm{~K} 7$ & $\begin{array}{l}\text { - Social networks, telephone } \\
\text { - Social networks, telephone }\end{array}$ & \\
\hline & PÇE & K5, K9 & $\begin{array}{l}\text { - Telephone } \\
\text { - Social networks, telephone }\end{array}$ & \\
\hline & PAMYO & K10, K11 & $\begin{array}{l}\text { - Social networks, telephone } \\
\text { - Social networks, telephone }\end{array}$ & \\
\hline & PBS & K12 & - Telephone, social networks & \\
\hline \multirow{5}{*}{ S7 } & PRTS & $\begin{array}{l}\mathrm{K} 1, \mathrm{~K} 2, \mathrm{~K} 6, \\
\mathrm{~K} 8\end{array}$ & $\begin{array}{l}\text { - Telephone } \\
\text { - Face to face } \\
\text { - Face to face } \\
\text { - Face to face (The solution } \\
\text { 'response' arrives so late from } \\
\text { the solution center, it is } \\
\text { unavailable.) }\end{array}$ & \multirow[t]{5}{*}{$\begin{array}{l}\text { - Face to face } \\
\text { - Telephone } \\
\text { - It's not possible to } \\
\text { communicate, } \\
\text { unavailable }\end{array}$} \\
\hline & PM & $\mathrm{K} 3, \mathrm{~K} 4, \mathrm{~K} 7$ & $\begin{array}{l}\text { - Face to face } \\
\text { - Face to face } \\
\text { - Telephone } \\
\end{array}$ & \\
\hline & PÇE & K5, K9 & $\begin{array}{l}\text { - Telephone, face to face } \\
\text { - Face to face }\end{array}$ & \\
\hline & PAMYO & K10, K11 & $\begin{array}{l}\text { - Face to face } \\
\text { - Face to face }\end{array}$ & \\
\hline & PBS & $\mathrm{K} 12$ & - Face to face, telephone & \\
\hline & PRTS & $\begin{array}{l}\mathrm{K} 1, \mathrm{~K} 2, \mathrm{~K} 6, \\
\mathrm{~K} 8\end{array}$ & $\begin{array}{l}\text { - It had a positive effect. I have } \\
\text { become more careful and } \\
\text { informed as a student. } \\
\text { - It has a positive effect. } \\
\text { - I use Internet for } \\
\text { communication mostly. } \\
\text { Therefore my strong } \\
\text { communication skills have }\end{array}$ & $\begin{array}{l}\text { - Positive } \\
\text { - I've become } \\
\text { informed. } \\
\text { - Increased } \\
\text { motivation. }\end{array}$ \\
\hline
\end{tabular}




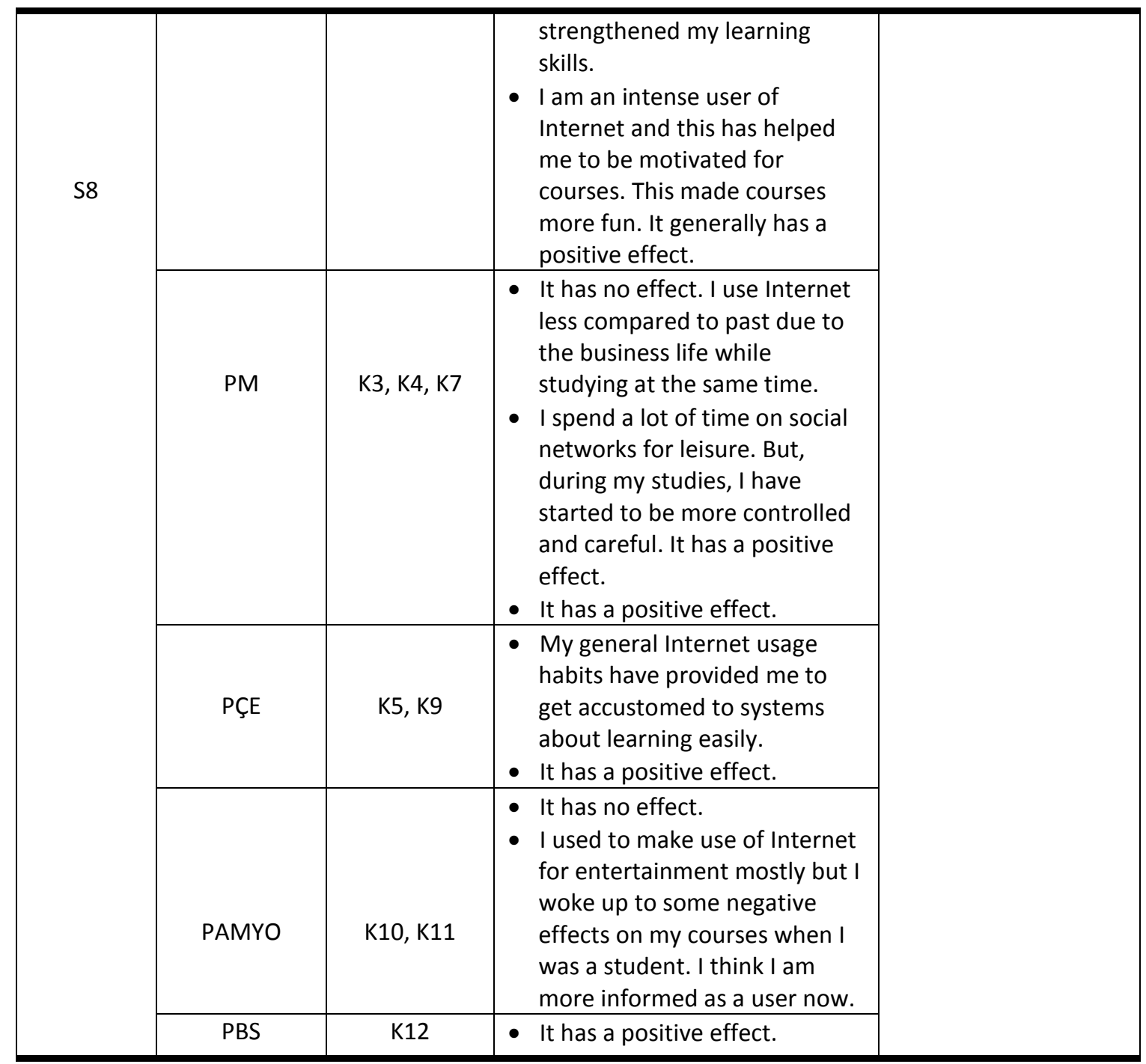

According to the data acquired as a result of the focus group interviews, it is concluded that distance education students, who are participants in this study, use Internet generally for 'communication', 'entertainment-leisure', 'information', 'following and sharing news' purposes. The time spent on social media applications is related to entertainment as well as sharing news and information.

It is safe to say that all the participants in the focus group interview use at least one social media application. Social media usage purposes include 'communication', 'making new friends', 'entertainment', 'following-sharing news and information' in this study. It is clear that the importance of social networks for students is remarkable. They use many social networks, particularly Facebook, as a communication tool for their educational studies.

As a result of the focus interview, the students stated that there are some distracting factors and technical problems with regard to automation systems. In addition, they noted that making use of 3 different automation systems is one of the distracting factors.

The expectations of students about the presentation formats of course content are mostly comprised of multi-content models. In short, the demand for the combination of written and 
audio-visual course contents is noteworthy. The demand for video contents was frequently brought up by the students. It is concluded that interest in only written contents gradually decreases.

The students generally prefer 'social networks', 'message boards' and 'e-mail' as a communication tool for their all distance education processes. They prefer 'e-mail', 'face to face' meetings and 'telephone' as a way to communicate with their instructors as well as 'social networks', 'telephone' and 'face to face' means with their classmates and 'face to face' meetings and 'telephone' with the registrar's office. They also reported that there is no way to communicate with the registrar's office. Social networks as a communication tool for students are the most important tools for their general educational studies as well as to communicate with their friends. Social networks are the most-preferred tools for these two options. However, it is noted that the students cannot make use of social networks to communicate with their instructors and the registrar's office.

The participants noted that their general Internet usage habits have a positive effect on their distance education Internet usage habits. This positive effect is direct as well as indirect. The students stated previously that they frequently use Internet for leisure and entertainment with no informed mentality, and it raises their awareness about what they study. They also pointed out that they start to use Internet in a more careful and qualified manner in classrooms. The students, who use Internet for entertainment quite often, stated that usage of Internet for entertainment purposes has no effect on their educational studies. Generally, the given answers are about the fact that education and entertainment are not independent from each other. The students pointed out that they are aware of it. In addition, some participants said they possess sufficient and effective Internet usage abilities and this leads to a positive effect on their educational studies.

The students argued and suggested that technical problems need to be solved by operators for a more effective and successful learning and teaching process. Technical incompetency of instructors is one of the major problems. The students found that teaching professionals are not competent enough for teaching practices in technical senses. It is indicated that most of them cannot even use microphones and cameras properly while Internet connection speed does not suffice to get the job done. The students of the Department of Radio, TV and Film in particular requested practical training. They said that the department needs to increase the applied methods and means. The students of the Department of Finance and Economics stated that teaching methods of numeric courses are quite inadequate and they must be improved. There are some recommendations about more flexible and advanced models in terms of time and space.

\section{Conclusion}

Within the scope of this study, distance education as a formal educational means was examined through the case of the Distance Education Center of Istanbul University. The Distance Education Center carried out learning and teaching practices along with a web-based content and tools just as many distance education systems around the world. The Center serves as a coordination hub while educational studies are carried out by the faculties. The study seeks an answer with regard to the relation between general Internet usage habits and Internet usage habits as a part of educational studies. 
The students of Distance Education in Istanbul University demand to engage more in their learning process and they reject one-way communication and monotype contents. In this sense, it is clear that distance education needs to be considered from a constructivist perspective. Therefore, students need to get involved more while offering many options for contents and transfer of such contents. All audiovisual means in particular need to be put into use efficiently in a communication process to design contents.

It is concluded that general usage habits of Internet are partially influential in usage habits for a learning process. General Internet usage habits of students, one way or another, offer a positive impact on Internet usage habits for a learning process. The students often make use of Internet and its tools in line with motivation for their studies.

Multi-dimensional and tumultuous Internet brings about negative impacts every now and then as well as learning-teaching activities that require major attention. The students believe that distractions can be eliminated by technical interventions.

Distance education is provided with assistance by conventional methods of education. Such methods literally create a new communication style whereas it is reinforced to demand for new communication tools. The students would like to further use social networks as a part of their educational studies. Meeting their demands can enhance their motivation. Therefore, further assistance needs to be provided for efforts to improve social network applications. Integrating audiovisual elements with social networks will result in positive outcomes.

The potential of Internet and what it offers lead to an increase in expectations of the students who are adapted Internet. The students demand making use of Internet means as a part of their general Internet usage habits. They think that the use of all the applications needs to be incorporated into official distance higher education practices.

Individuals have more responsibilities to assume with regard to learning on educational platforms where a constructive mentality prevails. Individuals are accountable for themselves when it comes to information to be acquired and new behavioral modalities to adopt. Therefore, constructive educational platforms need to be organized in a way to make sure that individuals engage in more interaction with their surroundings, and enjoy diversified educational models. Thanks to the diversity of educational models and platforms, individuals will be provided with a chance to test their knowledge they previously structure in their minds, rectify their mistakes if any, and even recant their past know-how and replace it with a new one.

\section{References}

Aggarwal, A. (2000). Web-based learning and teaching technologies: Opportunities and challenges. Hershey-USA: Idea Group.

Barbe, W., Swassing, R., \& Milone M. (1979). Teaching through modality strengths: Concepts and practices. Columbus, $\mathrm{OH}$ : Zaner-Bloser. 
Benson, L.; Harkavy, I. (2000). "Higher education's third revolution: The emergence of the democratic cosmopolitan civic university". Cityscape: A Journal of Policy Development and Research. 5 (1), 47-57.

Bhattacherjee, A., 2001. Understanding information systems continuance: An expectationconfirmation model. MIS Quarterly, 25(3), 351-370

Hillage, J., Pollard, E. (2001). Exploring e-learning. Brighton, UK: Institute for Employment Studies.

Holtz, S. (2002). Public relations on the net. ( $2^{\text {nd }}$ ed.) New York: Amacom.

Inceoglu, M. (2010). Tutum, algi, iletisim (5 $5^{\text {th }}$ ed.) İstanbul: Beykent Universitesi Yayinlari (No. $69)$.

Komito, L. \& Bates, J. (2009). Virtually local: Social media and community among Polish nationals in Dublin". ASLIB proceedings: New information perspectives, 61(3), 232-244.

Krueger, R. A. (1994). Focus groups: A practical guide for applied research. London: Sage Publications.

Limayem M. \& Cheung C. M.K. (2011) Predicting the continued use of Internet-based learning technologies: The role of habit. Behaviour \& Information Technology, 30(1), 91-99

Mayfield, A. (2008). What is social media, Retrieved on 16 April 2015 from http://www.icrossing.com/sites/default/files/what-is-social-media-uk.pdf

Oskay, U. (1999). Iletisimin $A B C^{\prime} s i,\left(^{\text {nd }}\right.$ ed.) Istanbul: Der.

Poster, M. (1997). Cyberdemocracy: The Internet and the public sphere. London and New Delhi: Sage.

Rheingold, H. (2000). The virtual community: Homesteading on the electronic frontier. Cambridge, MA: MIT Press.

Sharpe, R. \& Benfield, G. (2005). The student experience of e-learning in higher education. Brookes e-Journal of Learning and Teaching, 1(3). Retrieved on 14 October 2011 from http://bejlt.brookes.ac.uk/paper/the-student-experience-of-e-learning-in-highereducation-a-review-of-the-literature/

Tight, G. D. (2007). The role of learning style preference and instructional method in the acquisition of L2 Spanish vocabulary. Minneapolis, MN: University of Minnesota Press.

Tsai, S. \& Machado P. (2002). E-learning, online learning, Web-based learning, or distance learning: Unveiling the ambiguity in current terminology. Retrieved on 14 October 2011 from http://elearnmag.acm.org/archive.cfm?aid=568597

Correspondence: Firat Tufan, Assistant Professor, Faculty of Communication, Istanbul University, Beyazit, Istanbul, Turkey 